\title{
Carcass Characteristics of Kacang Goats Fed Ration Containing MH-1 Variety of Kapok Seed Meal (Ceiba pentandra, GAERTN.)
}

\author{
T. Hidjaz a, ${ }^{*}$ \& N. Djuarnani ${ }^{b}$ \\ aFaculty of Animal Husbandry, Mataram University \\ Jln. Majapahit No 62 Mataram Lombok NTB, Indonesia \\ ${ }^{b}$ Faculty of Animal Husbandry, Padjadjaran University \\ Jln. Raya Bandung-Sumedang Km. 21 Jatinangor, Sumedang 40600, Indonesia \\ (Received 24-06-2013; Reviewed 19-08-2013; Accepted 04-04-2014)
}

\begin{abstract}
This research aimed to study the carcass characteristics of Kacang goats fed ration containing kapok seed meal (KSM) as a component of the concentrate. The experiment was conducted in two stages. The first stage was to find out the best variety of kapok that will be used in the second experiment; the second stage was to determine the benefits of KSM on carcass characteristics. Twenty-five, 8 months old Kacang goats with initial body weight of $11.71 \pm 1.08 \mathrm{~kg}$, were used in this experiment. The animals were housed individually based on completely randomized design (CRD) with 5 treatments and 5 replications. The rations were based on forage:concentrate ratio of 50:50 dry matter basis. The ration contained concentrates, with increasing levels of KSM, i.e.: R0 (napier grass + concentrate: rice bran, coconut cake, corn, urea + 0\% KSM); R5 (R0 + KSM 5\%); R10 (R0 + KSM 10\%); R15 (R0 + KSM $15 \%)$; and R20 (R0 + KSM 20\%). Drinking water was provided ad libitum. The result of first stage showed that KSM variety of MH-1 would be used as a component of the concentrate on the second experiment. The increasing level of KSM in the rations had significant effect $(P<0.05)$ on physical characteristics of the carcass, such as dressing percentage $(44.35 \%)$, carcass length $(54.006 \mathrm{~cm})$, fleshing index $(130.59 \mathrm{~g} / \mathrm{cm})$, plumpness of leg $(87.48 \%)$, loin eye area $\left(5.06 \mathrm{~cm}^{2}\right)$, and percentage of carcass meat $(64.69 \%)$. It is concluded that MH-1 variety of KSM can be used as a feed component up to $20 \%$ in the goat ration.
\end{abstract}

Key words: carcass characteristics, Kacang goat, kapok seed meal (KSM)

\section{ABSTRAK}

Penelitian ini bertujuan untuk mempelajari karakteristik karkas kambing kacang yang diberi bungkil biji kapuk (BBK) dalam campuran konsentrat yang dilakukan melalui dua tahap percobaan. Tahap pertama untuk mencari varitas kapuk yang paling baik untuk digunakan dalam campuran konsentrat, tahap kedua dilakukan uji biologis untuk mempelajari manfaat bungkil biji kapuk pada karakteristik karkas kambing kacang. Penelitian dilakukan secara eksperimental menggunakan 25 ekor kambing kacang jantan, rataan bobot badan $11,71 \pm 1,08 \mathrm{~kg}$, umur sekitar 8 bulan yang ditempatkan pada kandang individual. Rancangan yang digunakan adalah rancangan acak lengkap, lima perlakuan ransum yang mengandung beberapa level BBK, dengan lima ulangan. Perlakuan yang diberikan ialah R0 (rumput gajah + konsentrat tanpa BBK), R5 (rumput gajah + konsentrat yang mengandung 5\% BBK), R10 (rumput gajah + konsentrat yang mengandung 10\% BBK), R15 (rumput gajah + konsentrat yang mengandung 15\% BBK), dan R20 (rumput gajah + konsentrat yang mengandung 20\% BBK). Pemberian pakan berdasarkan pada imbangan hijauan dan konsentrat sebesar 50:50 dari bahan kering. Tampilan karakteristik karkas, yaitu persentase karkas, panjang karkas, fleshing index, kemontokan paha, luas urat daging mata rusuk dan persentase daging karkas sebagai peubah yang diamati. Hasil penelitian menunjukkan bahwa BBK dari varitas MH-1 yang digunakan sebagai bahan pakan dalam campuran konsentrat. Pengaruh perlakuan terhadap penampilan produksi nyata meningkatkan bobot potong $(15,92 \mathrm{~kg})$. Peningkatan level bungkil biji kapuk dalam ransum nyata $(\mathrm{P}<0,05)$ meningkatkan persentase karkas $(44,35 \%)$, panjang karkas $(54,006 \mathrm{~cm})$, fleshing index $(130,59$ $\mathrm{g} / \mathrm{cm})$, kemontokan paha $(87,48 \%)$, luas urat daging mata rusuk $\left(5,06 \mathrm{~cm}^{2}\right)$, dan persentase daging karkas $(64,69 \%)$. Penggunaan BBK varitas MH-1 sampai $20 \%$ dalam konsentrat aman digunakan dalam ransum kambing.

Kata kunci: karakteristik karkas, kambing kacang, bungkil biji kapuk (BBK)

${ }^{*}$ Corresponding author:

E-mail: tahya14@gmail.com 


\section{INTRODUCTION}

In Indonesia, small ruminants especially goats are increasingly popular as supplier of good quality meat for villagers. Natural grass alone cannot cover daily requirements of goats due to its low nutritive value and, therefore, feed supplements are necessary. Kapok seed meal (KSM) is a potential source of feed ingredient for animals due to its high protein content. $\mathrm{KSM}$ is a potential feed source, derived from industrial waste plantation, which is given to goats as a mixture of concentrate in the diets. Potency of kapok seed expeller in Central Java and East Java is 16,858 tons per year. Kapok production centers in Java include: 1) West Java, the total area 5,568 ha; 2) East Java, located in 29 districts with a total area of 79,028 ha; 3) Central Java, located in 31 districts with a total area of 89,779 ha (Direktorat Jenderal Perkebunan, 2003). In 1930s, the Pati Residency controlled the world market with a yield of 22,600 tons per year (Lembaga Kapok Jawa Tengah, 1988).

Crude protein content of KSM ranged from 25\% to $30 \%$ and the crude fibre between $21.68 \%$ and $25.30 \%$ (PIER, 2002; Rajaram et al., 2012). KSM contained $128 \mathrm{~g}$ carbohydrate, $97 \mathrm{~g}$ ether extract, 3-8 g calcium, $11 \mathrm{~g}$ phosphor, $94 \mathrm{~g}$ ash, $10.4 \mathrm{~g}$ cyclopropenoid fatty acids (CPEFA) and $15 \mathrm{~g}$ tannins per $\mathrm{kg}$ (Narahari \& Asha-Rajini, 2003), gossypol 0.3-20 g/kg DM (Ari et al., 2011), gossypol $0.0037 \%$ and tannin $0.193 \%$ (Hartutik, 2001). KSM is rich in arginine, but low in cystine and methionine (Rajaram et al.,2012), and also contains essential minerals and trace elements that promote well being (Obiajunwa et al., 2005) and fatty acids glycosides, saponins and steroids (Friday et al., 2011; Sarkiyayi et al., 2009). Bioactive compounds and anti nutritional factor are found in KSM as reported by Narahari \& AshaRajini (2003); Akindahunsi \& Salawu (2005); Edeoga et al. (2006); Diarra (2010) including tyrosines and fatty acids with cyclopropene rings. Some of these anti-nutrient content (cyanogenic glycoside, trypsin inhibitors, phytate and oxalate) in KSM are of low values (Friday, 2011) which implies that the plant is safe for human and animal utilization.

Kapok seeds rich in crude protein ranging from $23 \%$ to $36.70 \%$ (Heuzé \& Tran, 2011; Anigo et al., 2013), crude fat 21\%-29\% (Hassan et al., 2006; Heuzé \& Tran, 2011; Anigo et al., 2013), carbohydrate $26.25 \mathrm{~g} / 100 \mathrm{~g}$, ash $5.87 \mathrm{~g} / 100 \mathrm{~g}$, calcium $1212.38 \mathrm{mg} / \mathrm{kg}$, and magnesium $234.58 \mathrm{mg} / \mathrm{kg}$ (Anigo et al., 2013). Kapok seed oil (KSO) has crude protein ranged from $36 \%$ to $44 \%$ (Yuniwati, 2012) and approximately $12 \%$ of CPEFA which consists of malvalic acid and sterculic acid (Gunstone, 2000). Additionally, it contains sterculic acids of $3.1 \%-3.6 \%$ and malvalic acids 7.6\%-7.9\% (Bianchini et al., 1981; Bianchini et al., 1982). KSO contains unsaturated and polyunsaturated fatty acids (PUFA) higher than coconut oil. Proportion of PUFA in KSO was $71.95 \%-71.98 \%$ (Widiyanto, 2010; Yuniwati, 2012; Frederic, 2013). About $62.32 \%$ of those was linoleic acid, whereas oleic and linolenic acid were $33.35 \%$ and $4.32 \%$, respectively (Widiyanto et al., 2013). Considering the crude fat content $(23.10 \%)$ of the kapok seed indicates that it is prom- ising for commercial benefits and very good source of edible oil (Hassan et al., 2006; Hassan et al., 2007) and the potential to be used as raw material for biodiesel (Putri et al., 2012). KSO obtained had clear bright yellowish color with offensive odour as was reported earlier (Kiran et al., 2012). Iodine value is, $76.80 \mathrm{~g}-94.98 \mathrm{~g} \mathrm{l} / 100 \mathrm{mg}$ oil and saponification value $179.77 \mathrm{mg}-183.0 \mathrm{mg} \mathrm{KOH} / \mathrm{g}$ oil as reported by Berry (2009) and Anigo et al. (2013). The oils with higher iodine and saponification value are suitable for soft soap and cosmetics production as well as for edible applications (Arkanni et al., 2005).

It has been recommended that the use of KSM for livestock and poultry should be limited due to the presence of anti-nutritive factors known as cyclopropenoid acid and gossypol. However, empirical data reporting the effects of those anti-nutritive factors on small ruminants are not known. Several studies have been conducted on the utilization of KSM as a feed supplement. In dairy cattle, Hartutik (2001) reported that the use of KSM up to $30 \%$, processing either by oven drying or by autoclave heating in the diets have significant effects on feed consumption and digestibility of the animals. Soeprapto (2005) reported that the use of $\mathrm{KSM}$ up to $20 \%$ in the diet gives the most efficient result on live weight gain and meat physical quality of Brahman Cross Steer (BX). Suwandyastuti (2004) stated that KSM which is one of protein source affects the essential minerals balances of growing male cattle. Therefore, the objective of this research was to evaluate the effect of KSM supplementation in the rations on the carcass characteristics of Kacang goats.

\section{MATERIALS AND METHODS}

\section{Experiment 1}

One of four kapok varieties namely SS-23 and SS-29 variety of Indica type, $\mathrm{MH}-1$ variety of Caribea type and Togo-B variety from cross breed Indica type and Caribea type would be selected based on the descriptive analysis of Halpen test and proximate analysis (dry matter, crude fiber, crude protein, ether extract, nitrogen free extract, ash, calcium and phosphor) (Table 1).

The Halpen color test is generally used for characterization of CPEFA on kapok seed oils. Equals volumes (about 1-3 mL) of oil, 1-pentanol, and carbon disulfide containing $1 \%$ sulfur were placed in a test tube and warmed in a steam bath for 10-15 min. All samples gave the characteristic red-pink color. The red-pink color was also used to detect the presence of CPEFA on kapok seed oils. Relative intensity of each sample was analyzed by spectrophotometer UV_Vis (varian model 634 S).

\section{Experiment 2}

Animals and management. Twenty-five male Kacang goats, age around 8 mo old with an initial average live weight of $11.71 \pm 1.08 \mathrm{~kg}$ were used. The animals were treated against internal and external parasites during the quarantine period of $7 \mathrm{~d}$ and adapted for $7 \mathrm{~d}$ to the experimental diets and pens. The animals were housed in in- 
Table 1. Chemical composition of four kapok varieties

\begin{tabular}{lrrrc}
\hline \multirow{2}{*}{ Nutrients (\%) } & \multicolumn{4}{c}{ Kapok varieties } \\
\cline { 2 - 5 } & MH-1 & SS-23 & SS-29 & Togo-B \\
\hline Dry matter & 87.28 & 87.04 & 89.13 & 88.28 \\
Crude fiber & 30.79 & 33.59 & 31.08 & 35.07 \\
Crude protein & 29.80 & 31.06 & 25.17 & 27.17 \\
Ether extract & 3.32 & 2.82 & 2.86 & 4.08 \\
NFE & 29.34 & 27.21 & 24.07 & 27.15 \\
Ash & 6.76 & 6.32 & 6.82 & 6.58 \\
Calcium & 0.15 & 0.24 & 0.22 & 0.15 \\
Phosphor & 0.14 & 0.20 & 0.13 & 0.12 \\
Cyclopropenoid acid & 0.420 & 0.414 & 0.405 & 0.461 \\
(A) & & & & \\
\hline
\end{tabular}

Note: $\mathrm{NFE}=$ nitrogen free extract; $\mathrm{A}=$ absorbance .

dividual pens $(1.25 \times 0.60 \times 0.80 \mathrm{~m})$, constructed of wood material, concrete floors and were located under a roof with well ventilated building in an open-sided barn.

Experimental diets. The goats were assigned into five experimental treatments. The treatments were concentrate with increasing level of KSM i.e. $0 \%, 5 \%, 10 \%, 15 \%$, and $20 \%$, respectively. The animals were given napier grass (Pennisetum purpureum) and concentrate consisting of rice bran, corn, coconut cake, urea, and KSM (Table 2). Diets consisted of $50 \%$ forage and $50 \%$ concentrate based on dry matter basis (Table 3). Animals were fed at $3.50 \%$ of their body weight, provided with clean drinking water.

Each animal was fed one of the five isocaloric and isoproteinaceous diets (Table 3): $\mathrm{R} 0=$ napier grass + concentrate; R5= R0 + KSM 5\%; R10= R0 + KSM 10\%; R15= R0 + KSM 15\%; and R20 = R0 + KSM 20\%. The concen-

Table 2. Ingredient and chemical composition of experimental diets

\begin{tabular}{lrrrrrr}
\hline & \multicolumn{5}{c}{ Diet ingredients } \\
\cline { 2 - 7 } Nutrient & $\begin{array}{c}\text { Napier } \\
\text { grass }^{\mathrm{a}}\end{array}$ & $\begin{array}{c}\text { Kapok } \\
\text { seed } \\
\text { meal }^{\mathrm{b}}\end{array}$ & $\begin{array}{c}\text { Coconut } \\
\text { meal }^{\mathrm{c}}\end{array}$ & $\begin{array}{r}\text { Rice } \\
\text { bran }^{c}\end{array}$ & Corn $^{\mathrm{c}}$ & Urea $^{c}$ \\
\hline Dry matter & 93.61 & 87.28 & 90.00 & 89.00 & 86.00 & \\
Crude protein & 11.53 & 29.79 & 21.50 & 7.70 & 10.60 & 0.285 \\
Crude fibre & 29.82 & 30.75 & 13.00 & 26.10 & 2.20 & \\
Ether extract & 1.43 & 3.31 & 2.70 & 4.20 & 4.70 & \\
NFE & 39.01 & 29.34 & 54.80 & 46.00 & 80.10 & \\
Ash & 18.21 & 6.76 & 8.00 & 16.00 & 2.50 & \\
Calcium & 0.23 & 0.15 & 0.19 & 0.10 & 0.02 & \\
Phosphor & 0.27 & 0.14 & 0.66 & 0.73 & 0.30 & \\
TDN & 60.52 & 52.06 & 76.00 & 49.00 & 89.00 & \\
\hline
\end{tabular}

Note: a Laboratory Analysis of Feed and Nutrition Animal Husbandry Faculty of UNRAM (2004), except TDN of elephant grass Kearl, L.C., (1982) and TDN of kapok seed meal from the formula Hartadi et al. (1993); 'baboratory Analysis of Agriculture Industrial Technology of Agriculture Technology Faculty, IPB (2004); 'Based on the nutrient content of Kearl (1982). trate was given at 7.00 a.m. and forage was given twice at 10.00 a.m. and 16.00 p.m.

Slaughter of animal's carcass process. After 14 wk experimental period, the goats were slaughtered. The animals were fasted for $12 \mathrm{~h}$ overnight (Preziuso et al., 1999) but were provided with clean water before they were slaughtered. The fasted weights of the animals were taken and were slaughtered by the halal method (Kadim et al., 2003) and exsanguinated by severing the jugular veins and carotid arteries (at atlanto-occipital aruchulation), trachea and oesophagus. After bleeding, the animals were partially skinned lying on their backs on the floor.

Thereafter, the animals were suspended by their Achilles tendon on $14 \mathrm{~cm}$ wired gambrel for further skinning. The hot carcass was further processed by removing the skin, head (at atlanto-occipital joints), fore and hind feet (at the carpal and tarsal joints), respectively. The carcass was opened up and eviscerated. Edible offal components (kidneys, liver, heart, lungs, spleen and pancreas), non-edible offal components (gastro intestinal tract, hooves, gall bladder (full) and ingesta) and fat depots such as scrotal fat, pelvic, kidney and gut fat (omental + mesenteric fat) were also removed. Empty body weight excluded the gastro-intestinal tract contents.

After removing the tail at the last sacral/first coccygeal vertebrae articulation, the carcass was split along the dorsal mid-line into two equal, left and right, using an electric saw. The right half carcass was weighed and then partitioned into neck, shoulder, breast-flank, loin, and leg. The cuts were weighed and expressed as a

Table 3. Formula of experimental diets (\%) and chemical composition (Dry matter basis)

\begin{tabular}{lrrrrr}
\hline \multirow{2}{*}{ Ingredients } & \multicolumn{5}{c}{ Diets } \\
\cline { 2 - 6 } & \multicolumn{1}{c}{ R0 } & \multicolumn{1}{c}{ R5 } & \multicolumn{1}{c}{ R10 } & \multicolumn{1}{c}{ R15 } & \multicolumn{1}{c}{ R20 } \\
\hline Napier grass & 50.00 & 50.00 & 50.00 & 50.00 & 50.00 \\
Coconut cake & 19.50 & 16.00 & 11.50 & 9.50 & 7.50 \\
Rice bran & 25.00 & 21.50 & 18.50 & 14.00 & 10.00 \\
Corn & 5.00 & 7.00 & 9.50 & 11.00 & 12.00 \\
KSM & - & 5.00 & 10.00 & 15.00 & 20.00 \\
Urea & 0.50 & 0.50 & 0.50 & 0.50 & 0.50 \\
Total & 100.00 & 100.00 & 100.00 & 100.00 & 100.00 \\
Nutrient composition & & & & \\
Crude protein & 15.04 & 15.02 & 15.07 & 15.20 & 15.38 \\
Crude fibre & 24.08 & 24.29 & 24.52 & 24.65 & 24.91 \\
NFE & 45.70 & 45.24 & 44.86 & 44.36 & 43.70 \\
Ether extract & 2.53 & 2.54 & 2.58 & 2.57 & 2.56 \\
Ash & 14.79 & 14.34 & 13.90 & 13.39 & 12.96 \\
Calcium & 0.18 & 0.18 & 0.17 & 0.17 & 0.17 \\
Phosphor & 0.46 & 0.43 & 0.39 & 0.35 & 0.32 \\
TDN & 61.78 & 61.79 & 61.73 & 61.94 & 61.95 \\
\hline
\end{tabular}

Note: $\mathrm{R} 0=$ napier grass + concentrate; R5= R0 + kapok seed meal (KSM) $5 \%$; R10= R0 + KSM 10\%; R15= R0 + KSM 15\%; and R20= R0 + KSM $20 \%$. NFE $=$ nitrogen free extract; TDN= total digestible nutrient by using Sutardi (1980) method. 
percentage of the total weight of the right half carcass.

Each cut was dissected and the tissues were separated to estimate the total carcass components in terms of lean meat, bone, subcutaneous fat and intermuscular fat. The loin eye area was determined by tracing the cross-section of the Longissimus muscle of the hind quarter of right halves of the carcasses cut between the 12 th and 13th ribs on a tracing paper. Several linear measurements were taken on the entire carcass (thigh circumferences, plumpness of leg) and on the half carcass (carcass length, leg length).

Measurements. The following live weight measurements were obtained in the morning before animals were slaughtered. Animals were weighed and fasted before slaughtered. Carcass weight was determined as the weight of the headless, footless, skinned, and eviscerated body of the animal with kidneys and kidney fat in place. Dressing percentage (\%) was defined as the carcass weight expressed as a percentage of slaughter body weight (Boggs \& Merkel, 1993; Sebsibe et al., 2007). Carcass length $(\mathrm{cm})$ was measured from the anterior edge of the syphilis (simphisis pubis) straight up to the middle of the edge of the visible part of the first rib (os costae) (Simela et al., 1999; Eniolorunda et al., 2011). Fleshing index was the ratio of carcass weight $(\mathrm{kg})$ to carcass length (cm) (Webb, 2005; Jibir et al., 2012). Plumpness of leg (\%): Comparison between thigh circumferences with thigh length expressed in percent (Fisher \& De Boer, 1994). Loin eye area $\left(\right.$ inch $\left.^{2}\right)$, obtained from eye-muscle (m. longissimus dorsi) area was measured after tracing the eyemuscle at $12 / 13^{\text {th }}$ rib position, using millimeter plasctic blocks (Boggs \& Merkel, 1993; Ponnampalam et al., 2003; El-Waziry, 2011). The proportion of lean-meat was calculated as the carcass meat expressed as a percentage of carcass weight (Cole, 1982; Alexandre et al., 2009).

Experiment design and statistical analysis. Completely randomized design (CRD) was used for this experiment. Data collected were statistically analyzed by using Analysis of Variant (ANOVA). The means were further evaluated with Duncan's Multiple Range Test (Steel \& Torrie, 1993).

\section{RESULTS AND DISCUSSION}

The chemical composition of four kapok varieties as test ingredient is presented in Table 1. Togo-B variety had higher DM, CF, EE and cyclopropenoid acid than SS-23 and MH-1 varieties, but it had lower CP, NFE and phosphor contents. While DM content obtained in the present study for SS-29 variety $(89.13 \%)$ was the highest. The averages of CP (28.30\%) and CF (32.63\%) for all kapok varieties in the present study were higher than $24.26 \%$ CP and $23.75 \%-28.76 \%$ CF as was reported by Muskita et al. (2011). The difference is due to variety of kapok used in this study is the prime seed of the Caribea type, Indica type and crossed of both of them. Hence, the KSM of MH-1 variety was used as the mixed concentrate due to: high protein level, the most preferred by farmers, the most widely planted than others, mainly on large plantations, has reached production of 2000 fruits/tree/ year, resistance against parasites, used for reforestation in conservation of degraded land.

The average of dressing percentage, carcass length, fleshing index, plumpness of leg, loin eye area and carcass meat percentage are presented in Table 4 . The result showed that KSM proportion in R5, R10, R15, and R20 treatments were significantly difference $(\mathrm{P}<0.05)$ than those of R0 (control) on dressing percentage, but were not significantly different each other. These may be attributed to carcass traits achieved by goat ration consumption (356.15-396.86 g/d) (Table 4). This means that the levels of KSM in concentrate not only could replace grass in the diet, but also increased weight gain of goats. This is due to goats fed R5, R10, R15, and R20 treatments consumed higher DM than control (Table 4). This condition also indicated that the ration of R5, R10, R15, and R20 treatments had better ability to increase gain of goats than other rations. The high gain was followed by a high slaughter weights and dressing percentage. Diet has been shown to be one of the main factors influencing the carcass weights, yield, cut ability and qualities in many species (Wood et al., 2008) and especially in goats (Webb et al., 2005). These results consistence with results reported by Ryan et al. (2007) and Haddad (2005) that increasing concentrates in meat-goat diets results

Table 4. Carcass percentage, carcass length, fleshing index, plumpness of leg, loin eye area and carcass meat percentage

\begin{tabular}{|c|c|c|c|c|c|c|}
\hline \multirow{2}{*}{ Variables } & \multicolumn{6}{|c|}{ Treatments } \\
\hline & R0 & R5 & R10 & R15 & $\mathrm{R} 20$ & SE \\
\hline DM consumption, $\mathrm{g} / \mathrm{h} / \mathrm{d}$ & 308.26 & 356.15 & 365.71 & 381.26 & 396.86 & \\
\hline Slaughter weight, kg & $14.08^{\mathrm{a}}$ & $15.60^{\mathrm{b}}$ & $16.40^{c}$ & $16.60^{c}$ & $16.92^{\mathrm{c}}$ & 1.14 \\
\hline Carcass percentage, $\%$ & $39.52^{\mathrm{a}}$ & $44.86^{\mathrm{b}}$ & $45.10^{\mathrm{b}}$ & $46.10^{\mathrm{b}}$ & $46.18^{b}$ & 2.76 \\
\hline Carcass length, cm & $45.57^{\mathrm{a}}$ & $54.47^{\mathrm{b}}$ & $56.61^{b}$ & $56.52^{\mathrm{b}}$ & $56.86^{\mathrm{b}}$ & 4.81 \\
\hline Fleshing index, $\mathrm{g} / \mathrm{cm}$ & $121.50^{\mathrm{a}}$ & $128.48^{\mathrm{b}}$ & $130.70^{\mathrm{b}}$ & $135.15^{c}$ & $137.14^{\mathrm{c}}$ & 6.14 \\
\hline Plumpness of leg, $\%$ & $83.02^{\mathrm{a}}$ & $88.01^{\mathrm{b}}$ & $88.10^{\mathrm{b}}$ & $88.97^{c}$ & $89.31^{\mathrm{c}}$ & 2.56 \\
\hline Loin eye area, $\mathrm{cm}^{2}$ & $3.06^{\mathrm{a}}$ & $4.68^{\mathrm{b}}$ & $5.52^{\mathrm{b}}$ & $5.99^{c}$ & $6.05^{\mathrm{c}}$ & 1.25 \\
\hline Carcass meat percentage, $\%$ & $60.36^{\mathrm{a}}$ & $62.52^{\mathrm{b}}$ & $64.80^{c}$ & $67.16^{\mathrm{d}}$ & $68.62^{\mathrm{d}}$ & 3.35 \\
\hline
\end{tabular}

Note: R0= napier grass + concentrate; R5= R0 + kapok seed meal (KSM) 5\%; R10= R0 + KSM 10\%; R15= R0 + KSM 15\%; and R20= R0 + KSM 20\%. Means in the same column with different superscripts differ significantly $(\mathrm{P}<0.05)$. 
in increased live-harvest weights, as well as increased carcasss weights. Moreover, increasing percentages of carcass was due to an increasing of slaughter weight (Aberle et al., 2001; Marichal et al., 2004). Rodrigues et al. (2009) also established a higher dressing percentage in goats in spite of the greater slaughter and carcass weight. Dressing percentage for this study varied from 39.52\% to $46.18 \%$. However, these values are in close agreement with that $40.20 \%-42.80 \%$ reported for the same breed of goats (Harris, 2004) and generally agrees with the values reported for various goat breeds worldwide (Kadim et al., 2004) that the mean dressing percentages varied between $38 \%$ and $44 \%$. Similar average dressing percentages were found by Simela et al. (2011) in South African indigenous goats, obtained values ranging from 39.0\% to $42.2 \%$. Agnihorti et al. (2006) had a research in Barbari goats, obtained values ranging from $43 \%-46 \%$. Other researchers reported the dressing percentage in the range of $45.00+3.12$ to $46.10+4.89 \%$ in Bligon goats (Widiarto et al., 2009). Results of other studies with Etawah Crossbred (EC) and Kejobong goats (Sumardianto et al., 2013) were $40.39 \%$ and $44.69 \%$, respectively. However, Hasnudi et al. (2006); Nasser (2006); Padang \& Irmawaty (2007); and Sodiq (2011) found a slightly higher average dressing percentage in Kacang goats i.e. $43.20 \%-51.64 \%$. Sent et al. (2004) and Pi et al. (2005) also found a higher average dressing percentage $(49.0 \%)$ in Local Indian goats and Boer goats. Similarly, Johnson et al. (2010) observed a higher dressing percentage (46\%-49\%) in meat of goats and Kebede et al. (2008) in Arasi-Bale goats. Sumardianto et al. (2013) reported that dressing percentage was lower $(37.50 \%)$ in male Kacang goat.

Table 4 shows the result of carcass length measurement of Kacang goats fed with graded levels of KSM. Carcass length measurement for animals on R5, R10, $\mathrm{R} 15$, and R20 treatments were significantly $(\mathrm{P}<0.05)$ higher than control, but were not significantly different from each other. The higher carcass length in goats supplemented with KSM in the diet was probably due to the nutrient value of the feed (Table 2) and possibly by dry matter intake (Table 4). These may be attributed to the higher carcass length showing the different quantities of tissues, especially meat, bone and fat in term of growth rate and consequently increased slaughter weight and carcass weights. These results consistence with results reported by Marichal et al. (2003); Gul et al. (2005); and Gebreyesus et al. (2012) that slaughter weight and carcass weight correlated with measurement of body and carcass length. The carcass length of this study varied from 45.57 to $56.86 \mathrm{~cm}$, however, these values were in close agreement with that $49-57 \mathrm{~cm}$ reported for different breeds of goats (Alexandre et al., 2009). Ekiz et al. (2010) also found average $(56.90 \mathrm{~cm}$ ) carcass length of Saanen and Maltese goats. Results of other studies with three Ethiopian goats breeds (the Afar goat breed, Central Highland/CHG goat breed and Long-eared Somali/LES goat breed) (Sebsibe et al., 2007) showed a higher mean carcass length than this present experiment. This was probably due to the small size of the Kacang goat in comparison with the Ethiopian goats. Others reported that the carcass length was in the range of 41.15-46.20 $\mathrm{cm}$ in Red Sokoto goats (Attah et al., 2004), which were similar to the present experiment, however, determined shorter carcass length in the range $35.93-39.45 \mathrm{~cm}$ in the West African Dwarf goats. Mourad et al. (2001) reported the carcass length of West African Dwarf goats was 46.8 $\mathrm{cm}$ at the age of 12-18 mo.

The effect of KSM on fleshing index (FI) was significantly $(\mathrm{P}<0.005)$ heavier and higher in R20 and R15 treatments than R10, R5 treatments and control. Carcasses of R10 and R5 treatments goats moreover displayed better fleshings $(\mathrm{P}<0.05)$ than control. The increase in lean, fat tissues, and shorter carcass length might explain the difference. This is especially a situation that will see to apparent increases in carcass weight (5.60-7.80 $\mathrm{kg}$ ) at the expense of carcass length. FI was the ratio of carcass weight to carcass length, which was used in the assessment of carcass conformation. The average of FI obtained in this study ranged from 121.50 to $137.14 \mathrm{~g} / \mathrm{cm}$ $(130.59 \mathrm{~g} / \mathrm{cm})$. However, these values are in close agreement with that $130.80 \mathrm{~g} / \mathrm{cm}$ in Afar goats and 129.30 $\mathrm{g} / \mathrm{cm}$ in CHG goats reported for different breeds of goat (Sebsibe et al., 2007), but lower than the FI of Sokoto Red goats and Sahel goats which were $151.0 \mathrm{~g} / \mathrm{cm}$ and 146.7 $\mathrm{g} / \mathrm{cm}$ (Jibir et al., 2012) and LES goats was $145.6 \mathrm{~g} / \mathrm{cm}$ (Sebsibe et al., 2007). This was mainly due to the increase in lean and fat tissues (Ruvuna et al., 1992; Awah \& Adeleye, 1994). Forrest et al. (1975) documented that the skeletal growth in goats stop earlier than muscle and adipose.The author noted that the FI is influenced by the increase in slaughter weight. These results consistence with Yeates et al. (1975) and Kempster (1983) that the slaughter weigth can be used as a predictor of FI. The value of FI implies that the carcass contained more lean.

Diet had significant effect on the plumpness of leg of the carcass (Table 4). The results showed that KSM proportion in R20 and R15 treatment were significantly $(\mathrm{P}<0.05)$ higher than R10, R5 treatments and control on plumpness of leg. R10 and R5 treatments were significantly $(\mathrm{P}<0.05)$ higher than control. This may be attributed to higher slaughter weight, whilst width and conformation of carcass varied indicating different quantity of the tissues. This leads to significant increase in the weights of carcass, carcass component and carcass pieces and for the linear carcass measurements (thigh circumference and thigh length). The wider plumpness of goat leg may in parts be accounted for by their significantly higher slaughter weight and carcass length (Table 4). In addition, the normal processes of tissue growth in the carcass are additively diet-related (Attah et al., 2004). This was demonstrated by the increase of plumpness of leg with the increasing of the thigh circumference expressed as a percentage of thigh length. The width of plumpness of leg described the development of muscle on thigh-section. These results consistence with Yeates et al. (1975) that reported the degree of plumpness of leg is used to describe the body and carcass conformation, thus can be used to describe the conformation of rearquarters section. Moron-Fuenmayor \& Clavero (1999) stated that the conformation of leg is an indicator of the muscularity of the animals.

KSM proportion in the R20 and R15 treatments were significantly $(\mathrm{P}<0.05)$ higher than $\mathrm{R} 10, \mathrm{R} 5$ treatment and control on loin eye area. These may be attributed to 
the carcass yield and body weight. R10 and R5 treatments had the larger loin eye area than those of control. This condition indicated that increasing KSM levels in the diet fed to Kacang goats increased slaughter weight and dressing percentage. Lawrie (1991) stated that loin eye area was closely related to slaughter weight and carcass percentage. Jibir et al. (2012) reported that in semiarid zone goat carcass with high percentage (46.72\%) produced $8.06 \mathrm{~cm}^{2}$ of loin eye area compared to the percentage of carcass $(46.42 \%)$ produced loin eye area of $7.91 \mathrm{~cm}^{2}$. In this study loin eye area was significantly different, this condition due to the widespread value of loin eye area associated with carcass meat percentage. These results consistence with Boggs \& Merkel (1993) that widespread of loin eye area reflected the meat of carcass and the muscle of animals. The rib eye area is often used to estimate carcass meat, yield, lean meat, bone and carcass weight. Mean loin eye area of all experimental goats was $5.06 \mathrm{~cm}^{2}$, the value was lower and outside the $7.38-8.62 \mathrm{~cm}^{2}$ range reported by Das \& Rajkumar (2010). This was probably because Das \& Rajkumar (2010) used different breed of goats. The value was however within the $\left(6.43-8.26 \mathrm{~cm}^{2}\right)$ reported by Sebsibe et al. (2007). Value of loin eye area for this study varied from 3.06-6.05 $\mathrm{cm}^{2}$. This value was lower than Karami et al. (2010) that reported the value of loin eye area ranged from 10.20-12.10 $\mathrm{cm}^{2}$. This difference was due to the breed of the goats (Malaysian-local goats). Results of other studies showed that the loin eye area on lamb varied from $4.22-7.69 \mathrm{~cm}^{2}$ (Duldjaman, 2005). Wider variation was reported by Yusuf et al. (2014) from $4.79 \pm 0.10$ to $9.08 \pm 0.64 \mathrm{~cm}^{2}$. The results of Brady et al. (2003) research showed that the loin eye area ranged from $11.61-25.60 \mathrm{~cm}^{2}$, this variation was due to the differences in breed and final body weight.

The effect of KSM on carcass meat percentage was significantly $(\mathrm{P}<0.05)$ higher than $\mathrm{R} 20, \mathrm{R} 15$ treatments and control. Carcass meat percentage of goats on R10 and R5 treatments was significantly $(\mathrm{P}<0.05)$ higher than those of control. These results attributed to the diet that had significant effect on the slaughter weight and carcass weight. Slaughter weight was the best predictor of carcass components and carcass weight was the best predictor of carcass meat (Simela et al., 1999; Hanna, 2010). In this study, the experimental animals were fed isocaloric and isoproteinaceous diets (Table 3). However, the KSM had high crude protein in concentrate (Table 1) not only increased carcass weight, but also increased distribution of muscle on carcass goats. This condition indicated that goat carcass with high carcass weight $(7.40-7.80 \mathrm{~kg})$ produced $4796.40-5430.86 \mathrm{~g}$ carcass meat compared to the weight of carcass $5.60-7.00 \mathrm{~kg}$ produced 3380.87-4375.86 g meat of carcass. The tissues distribution of the goat carcasses in this study varied from $60.36 \%-68.62 \%$ lean. These values are in close agreement with that $59.50 \%-65.60 \%$ reported for the same breed of goats (Harris, 2004; Hasnudi et al., 2006; Sumardianto et al., 2013). The carcass meat measurements of the goats used in this study was comparable to other breeds in the region, namely the Creole goats of Guadeloupe (Alexandre et al., 2009), the local goats of Malaysia (Karami et al., 2010) and indigenous goats of South
African (Simela et al., 2011), for example; it was reported that mean proportion of muscle percentage for Creole goats was approximately 70\% (Alexandre et al., 2009). The carcass meat percentage of Malaysian local goats ranged from $63.40 \%$ to $67.80 \%$ (Karami et al., 2010) and the South African indigenous goats varies from $61.80 \%$ $64.70 \%$ (Simela et al., 2011). The largest component of tissues was muscle and this consistence with Blakely \& Bade (1991) that the main component of muscle tissue is protein.

\section{CONCLUSION}

The inclusion of kapok seed meal in the ration is potential to improve carcass characteristics of Kacang goats. The KSM of MH-1 variety can be included up to $20 \%$ in the concentrate ration.

\section{ACKNOWLEDGEMENT}

I am very grateful to Program Pascasarjana UNPAD Bandung. The study was supported by Beasiswa Pendidikan Pascasarjana (BPPS), Ministry of Education and Culture, Indonesia.

\section{REFERENCES}

Aberle, E. D., E. S. Reeves, M. D. Judge, R. E. Hunsley, \& T. W. Perry. 1981. Palatability and muscle characteristics of cattle controlled weight gain: Time on a high energy diets. J. Anim. Sci. 52: 757-763.

Agnihorti, M. K., V. Rajkumar, \& T. K. Dutta. 2006. Effect of feeding complete rations with variable protein and energy levels prepared using by-products of pulses and oilseeds on carcass characteristics, meat and meatball quality of goats. Asian-Aust. J. Anim. Sci. 19:1437-1449.

Akanni, M. S., S. A. Adekunle, \& E. A. Oluyemi. 2005. Physicochemical properties of some non-conventional oil seed. J. Food Technol. 3: 177-181.

Akindahunsi, A. A. \& S. O. Salawu. 2005. Phytochemical screening and nutrient- anti-nutrient composition of selected tropical green leaf vegetables. Afr. J. Biochem. 4: 97-101.

Alexandre, G., L. Limea, A. Fanchonne, O. Coppry, M. Mandonnet, \& M. Boval. 2009. Effect of forage on goat meat production: carcass characteristics and composition of Creole kids reared either at pasture or indoors in the humid tropics. Asian-Aust. J. Anim. Sci. 22: 1140-1150.

Anigo, K. M., B. M. D. Dauda, A. B. Sallau, \& I. E. Chindo. 2013. Chemical compotition of kapok (Ceiba pentandra) seed and physicochemical properties of its oil. Nigerian J. Basic App. Sci. 21: 105-108.

Ari, M. M., R. E. Barde, M. D. Ogah, A. Yakubu, \& V. E. Aya. 2011. Performance of broilers fed silk cotton seed (Ceiba petandra) based diets. PAT 7: 20-28.

Attah, S., A. O. Okubanjo, A. B. Omojola, \& A. O. K. Adesehinwa. 2004. Body and carcass liniear measurements of goats slaughtered at different weights. Livestock Res. Rural Development. 16:8.

Awah, A. A. \& I. O. A. Adeleye. 1994. The development of lean muscle, bone and fat in the West Africa Dwarf goat of Nigeria maintained on good plane of nutition. Tropiculture 12: $141-144$.

Berry, S. K. 2009. The characteristics of the kapok (Ceiba pentandra Gaertn.) seed oil. Pertanika J. Trop. Agric. Sci. 21: 1-4.

Bianchini, J. P., A. Ralaimanarivo, \& E. M. Gaydon. 1981. De- 
termination of cyclopropenoic and cyclopropanoic fatty acids in cotton seed and kapok seed oils by gas-liquid chromatography. Anal. Chem.53: 2194-2201. http://dx.doi. org/10.1021/ac00237a012

Bianchini, J. P., A. Ralaimanarivo, \& E. M. Gaydon. 1982. Reversed-phase high-performance liquid chromatography of fatty acid methyl esters with particular reference to cyclopropenoic and cyclopropanoic acids. J. High Res. Chromatog. 5: 199-204. http://dx.doi.org/10.1002/ jhrc. 1240050406

Blakely, J. \& D. H. Bade. 1991. Ilmu Peternakan. Edisi keempat. Gadjah Mada University Press.

Boggs, D. L. \& R. A. Merkel. 1993. Live Animal Carcass Evaluation and Selection Manual. Fourth editon.Kendall/Hunt Publishing Company Iowa-USA.

Brady, A. S., K. E. Belk, S. B. Le Valley, N. L. Dalsted, J. A. Scanga, J. D. Tatum, \& G. C. Smith. 2003. An evaluation of the lamb vision system as a predictor of lamb carcass red meat yield percentage. J. Anim. Sci. 81: 1488-1498.

Cole, V. G. 1982. Beef Cattle Production Guide. NSWUP ed. Mc Arthur Press, Parramatta, New South Wales. p: 230

Das, A. K. \& V. Rajkumar. 2010. Comparative study on carcass characteristics and meat quality of three Indian goat breed. The Indian J. Anim. Sci. 80: 1014-1018.

Diarra, S. S., B. A. Usman, J. U. Igwebuike, \& A. G. Yisa. 2010. Breeding for efficient phytate-phosphorus utilization by poultry. Int'1 J. Poultry Sci. 10: 923-930.

Direktorat Jenderal Perkebunan. 2003. Statistik Perkebunan Indonesia. Departemen Pertanian. Direktorat Jenderal Bina Produksi Perkebunan.

Duldjaman, M. 2005. Kualitas karkas domba yang diberi pakan rumput kering dan ditambah ampas tahu. J. Indon. Trop. Agric. 30: 81-87.

Edeoga, H. O., G. Omosun, \& L. C. Uche. 2006. Chemical composition of Hyptis suaveolens and Ociumum gratissimum legbirds from Nigeria. Afr. J. Biotechnol. 5: 891-895.

Ekiz, B., M. Ozcan, A. Yilmaz, C. Tolu, T. Savas. 2010. Carcass measurements and meat quality characteristics of dairy suckling kids compared to an indigenous genotype. Meat Sci. 85: 245-249. http://dx.doi.org/10.1016/ j.meatsci.2010.01.006

El-Waziry, A. M., A. N. Al-Owaimer, G. M. Suliman, E. S. Hussein, \& M. A. Abouheif. 2011. Performance, carcass characteristics and meat quality of intact and castrated Ardhi goat kids fed high energy diet. J. Anim. Vet. Adv. 10:21572162. http://dx.doi.org/10.3923/javaa.2011.2157.2162

Eniolorunda, O. O., E.S. Apata, \& A. O. Okubanjo. 2011. Body and carcass linear measurement of rams fed graded levels of biscuit waste based diet. Afr. J. Food. Sci. 5:614-619.

Fisher, A. V. \& H. De Boer. 1994. Carcass measurements and dissection procedures. The EAAP standard method of sheep carcass assessment. Livest. Prod. Sci. 38: 149-159. http://dx.doi.org/10.1016/0301-6226(94)90166-X

Forrest, J. C., E. D. Aberle, H. B. Hedrick, M. D. Judge, \& R. A. Merkel. 1975. Principles of Meat Science. First edition. W.H. Freeman and Co. San Fransisco.

Frederic, N. P. 2013. Pembuatan biodiesel dari minyak biji kapok dengan proses esterifikasi transesterifikasi. J. Tek. Kimia dan Industri 2: 262-266.

Friday, E. T., O. James, O. Olusegun, \& A. Gabriel. 2011. Investigation on the nutritional and medicinal potentials of Ceiba pentandra leaf: A common vegetables in Nigeria. Int'1 J. Plant physiology Biochem. 3: 95-101.

Gebreyesus, G., A. Haile, \& T. Dessie. 2012. Body weight prediction equations from different linear measurements in the Short-Eared Somali goat population of Eastern Ethiopia. J. Anim Sci. 6: 90-93.

Gul, S., O. Gorgulu, M. Keskin, O. Bicer, \& A. San. 2005. Some prediction equations of live weight from different body measurements in Shami (Damascus) goats. J. Anim.
Vet. Adv. 4: 532-534.

Gunstone. 2000. Cyclic Acids. F.D. Gunstone. Scottish Crop Research Institute. Invergowrie, Dundee, Scotland.

Haddad, S. G. 2005. Effect of dietary forage: Concentrate ratio on growth performance and carcass characteristics of growing Baladi kids. Small Rumin. Res. 57:43-49. http:// dx.doi.org/10.1016/j.smallrumres.2004.05.001

Hanna, S. S. 2010. Estimation of carcass composition of sheep, goats and cattle by the urea dilution technique. Pak. J. Nutr. 9: 1107-1112. http://dx.doi.org/10.3923/pjn.2010.1107.1112

Harris, I. 2004. Pengaruh seng organik dalam pakan terhadap konsumsi bahan kering dan penampilan karkas kambing Kacang. J. Indon. Trop. Anim. Agric. 29: 80-85.

Hartutik. 2001. Pengaruh penggunaan bungkil biji kapuk (Ceiba pentandra, Gaertn.) dalam konsentrat terhadap konsumsi dan kecernaan ransum pada sapi PFH jantan berfistula rumen. Med. Pet. 24: 91-93.

Hasnudi, Yunilas, \& F. Marbun. 2006. Pemanfaatan hasil sampingan perkebunan sebagai pakan tambahan bagi kambing Kacang terhadap karkas serta perbandingan daging dan tulang selama penggemukan. Jurnal Agribisnis Peternakan 2: 49-55.

Hassan, L. G., A. M. Sokoto, S. M. Dangoggo, \& M. J. Ladan. 2006. Proximate, amino acids and minerals composition of silk cotton seeds (Ceiba pentandra). Afr. J. Natural Sci. 9: 29-35.

Hassan, L. G., K. J. Umar, \& A. S. Muhammed. 2007. Physicochemical analysis and biofuel properties of silk cotton tree (Ceiba pentandra (L.) Gaertn.) seed oil. Biological and Environmental Sciences Journal for the Tropic. 4: 71-74

Heuze, V. \& G. Tran. 2011. Kapok (Ceiba pentandra). Feedipedia.org. A project by INRA, CIRAD, AFZ and FAO. http:// www.trc.zootechnie.fr/node/48. Retrieved on September 9, 2011. 11:30

Jibir, M., W. A. Hassan, S. A. Maigandi, S. Garba, A. Bello, S. A. Hena, M. A. Umaru, \& Y. A. Adamu. 2012. Yield characteristics on goat's meat in the semi-arid zone of northwestern Nigeria. Sci. J. Agric. 1: 92-99.

Johnsons, C. R., S. P. Doyle, \& R. S. Long. 2010. Effect of feeding system on meat goat growth performance and carcass traits. Sheep Goat Res. J. 25: 78-82.

Kadim, I. T., O. Mahgoub, D. S. Al-Ajmi, R. S. Al-Maqbaly, N. M. Al-Saqri, \& A. Ritichie. 2004. An evaluation of the growth and carcass and meat quality characteristics of Omani goat breeds. Meat Sci. 66: 203-2010. http://dx.doi. org/10.1016/S0309-1740(03)00092-5

Karami, M., A. R. Alimon, Y. M. Goh, A. Q. Sazili, \& M. Ivan. 2010. Effects of dietary herbal anti oxidants supplemented on feedlot growth performance and carcass composition of male goat. American Journal of Animal and Veterinary Sciences 5: 33-39. http://dx.doi.org/10.3844/ajavsp.2010.33.39

Kebede, T., T. Lemma, H. Dinka, M. Guru, \& A. Sisay. 2008. Growth performance and carcass characteristics of ArasiBale goats castrated at different ages. J. Cell Anim. Biol., 2: 187-194.

Kempster, A. J. 1983. Carcass quality and its measurement in sheep. In: Haresign, W. (editor) Sheep Production. Butterworths. London/Boston/Durbin/Singapore/Sydney/Toronto/Wellington.

Kiran, Ch. R., Y. Madhavi, \& T. R. Rao. 2012. Evaluation of phytochemicals and antioxidant activities of Ceiba pentandra (kapok) seed oil. Journal of Bioanalysis \& Biomedicine 4:68-73.

Lawrie, R. A. 1991. Meat Science. Fifth English edition. Pergamon Press.

Lembaga Kapok Jawa Tengah. 1988. Ekspor kapok Jawa Tengah dan Indonesia tahun 1933-1988.

Marichal, N., N. Castro, J. Capote, M. J. Zamorano, \& A. Arguello. 2004. Effects of live weight at slaughter $(6,10$ and $25 \mathrm{~kg}$ ) on kid carcass and meat quality. Livest. Prod. Sci. 83: 
247-256. http://dx.doi.org/10.1016/S0301-6226(03)00113-1

Moron-Fuenmayor, O. E. \& T. Clavero. 1999. The effect of feeding system on carcass characteristics, non-carcass components and retail cut percentage of lambs. Small Rumin. Res. 34: 57-64. http://dx.doi.org/10.1016/S0921-4488(99)00038-3

Mourad, M., G. Ghanamou, \& I. B. Blade. 2001. Carcass characteristics of West African Dwarf goats under extensive system. Small Rumin. Res. 42:83-86. http://dx.doi.org/10.1016/ S0921-4488(01)00211-5

Muskita, W. H., E. Harris, M. A. Suprayudi, \& D. Jusadi. 2011. Effect of kapok seed meal (Ceiba petandra): Related to digestive enzyme activity of juvenile shrimp (Litopenaeus vannamei). Ichthyos 10: 89-94.

Narahari, D. \& R. Asha Rajini. 2003. Chemical composition and nutritive value of kapok seed meal for broiler chickens. British Poultry Sci. 44:505-509. http://dx.doi.org/10.1080/0 0071660310001598274

Nasser, A. 2006. Pengaruh pemberian pakan dalam waktu berbeda terhadap bobot karkas dan persentase karkas kambing Kacang jantan. J. Agroland 13: 282-287.

Obiajunwa, E. I., F. M. Adebiyi, \& P. E. Omoda. 2005. Determination of essential minerals and trace elements in Nigerian sesame seeds, using TXPF technique. PAK. J. Nutr. 4: 393395.

Padang \& Irmawaty. 2007. Pengaruh jenis kelamin dan lama makan terhadap bobot dan persentase karkas kambing Kacang. Jurnal Agrisistem 3: 13-20.

Phelps, R. A., F. S. Shentone, A. R. Kemmerer, \& R. J. Evans. 1965. A Review of Cyclopropenoid compounds: biological effect of some derivatives. J. Poultry Sci. 44: 358.

PI, Z. K., Y. M. Wu, \& J. X. Liu. 2005. Effect of pretreatment and pelletization on nutritive value of rice straw-based total mixed ration, and growth performance and meat quality of growing Boer goats fed on TMR. Small Rumin. Res. 56: 81-88.

PIER. 2002. Ceiba pentandra (L.) GAERTNER. Bombacaceae. Pacific Island Ecosystem at Risk (PIER).

Ponnampalam, E. N., B. J. Hosking, \& A. R. Egan. 2003. Rate of carcass components gain, carcass characteristic and muscle longissimus tenderness in lambs fed dietary protein sources with a low quality roughage diet. Meat Sci. 63:143-149. http://dx.doi.org/10.1016/S0309-1740(01)00202-9

Preziuso, G., C. Russo, L. Casarosa, G. Campodani, S. Piloni, \& D. Cianci. 1999. Effect of diet energy source on weight gain and carcass characteristics of lambs. Small Rumin. Res. 33: 9-15. http://dx.doi.org/10.1016/S0921-4488(98)00202-8

Putri, E. M. M., M. Rachimoellah, N. Santoso, \& F. Pradana. 2012. Biodiesel production from kapok seed oil (Ceiba pentandra) through the transesterification process by using cao as catalyst. Global Journal of Researches in Engineering Chemical Engineering 12: 6-11.

Rajaram, V., J. Syama Dayal, K. Ambasankar, \& S. Ahamad Ali. 2012. Silk cotton cake as an alternate protein source in the diet of tiger shrimp, Penaeus monodon Fabricus 1798, and its effects on growth, nitrogen utilization and metabolism. Indian J. Fish. 59: 101-110.

Rodrigues, L., H. C. Gonçalves, B. B. L. Medeiros, G. I. L. Canizares, J. J. L. Menezes, \& M. F. Martins. 2009. Carcass characteristics of young goats from different breed groups under two feeding system. Tropical and Sub-tropical Agroecosystems 11: 245-247.

Ruvuna, F., J. F. Taylor, M. Okeyo, M. Wanyoike, \& C. Ahuya. 1992. Effects of breed and castration on slaughter weight and carcass composition of goats. Small Rumin. Res. 7: 175-183. http://dx.doi.org/10.1016/0921-4488(92)90206-J

Ryan, S. M., J. A. Unruh, M. E. Corrigan, J. S. Drouillard, \& M. Seyfert. 2007. Effects of concentrate level on carcass traits of Boer crossbred goats. Small Rumin. Res.73: 67-76. http://dx.doi.org/10.1016/j.smallrumres.2006.11.004

Sarkiyayi, S., S. Ibrahim, \& M. S. Abubakar. 2009. Toxicologi- cal studies of Ceiba pentandra Linn. Afr. J. Biochem. Res. 3: 279-281.

Sebsibe, A., N. H. Casey, W. A. vanNiekerk, A. Tegegne, \& R. J. Coertze. 2007. Growth performance and carcass characteristics of three Ethiopian goat breeds fed grainless diets varying in concentrate to roughage ratios. S. Afr. J. Anim Sci. 37: 221-232. http://dx.doi.org/10.4314/sajas.v37i4.4094

Sen, A. R., A. Santra, \& S. A. Karim. 2004. Carcass yield, composition and meat quality attributes of sheep and goat under semiarid conditions. Meat Sci. 66: 757-763. http:// dx.doi.org/10.1016/S0309-1740(03)00035-4

Simela, L., L. R. Ndlovu, \& L. M. Sibanda. 1999. Carcass characteristics of the marketed Matebele goat from South-western Zimbabwe. Small Rumin. Res. 32:173-179. http://dx.doi. org/10.1016/S0921-4488(98)00182-5

Simela, L., E. C. Webb, \& M. J. C. Bosman. 2011. Live animal and carcass characteristics of SouthAfrican indegenous goats. S. Afr. J. Anim. Sci. 41: 1-15. http://dx.doi.org/10.4314/sajas. v41i1.66032

Sodiq, A. 2011. Prediksi bobot dan konformasi karkas kambing lokal menggunakan prediktor bobot potong dengan berbagai model regresi. Agripet 11: 1-7.

Soeprapto, H. 2005. Keragaan produksi sapi Brahman Cross Kastrasi yang diberi pakan konsentrat mengandung bungkil biji kapok. J. Anim. Prod. 7: 189-193.

Steel, R. G. D. \& J. H. Torrie. 1993. Prinsip dan prosedur statistika suatu pendekatan biometrik. Penerjemah: B. Sumantri. Edisi Ke-3. Gramedia Pustaka Utama, Jakarta.

Sumardianto, T. A. P., E. Purbowati, \& Masykuri. 2013. Karakteristik kambing Kacang, kambing Peranakan Etawa, dan kambing Kejobong jantan pada umur satu tahun. Anim. Agric. J. 2: 175-182.

Sutardi, T. 1980. Landasan Ilmu Nutrisi I. Fakultas Peternakan, Institut Pertanian Bogor.

Suwandyastuti, S. N. O. 2004. Essential-mineral balance on growing male cattle. J. Anim. Prod. 6: 101-109.

Webb, E. C., N. Casey, \& L. Simela. 2005. Goat meat quality. Small Rumin. Res. 60: 153-166. http://dx.doi.org/10.1016/ j.smallrumres.2005.06.009

Wood, J. D., M. Enser, A. V. Fisher, G. R. Nute, P. R. Sheard, R. I. Richadson, S. I. Hugher, \& F. M. Whittington. 2008. Fat deposition, fatty acid composition and meat quality: A review. Meat Sci. 78:343-358. http://dx.doi.org/10.1016/ j.meatsci.2007.07.019

Widiarto, W., R. Widiati, \& I. G. S. Budisatria. 2009. Pengaruh berat potong dan harga pembelian domba dan kambing betina terhadap gross margin jagal di rumah potong hewan Mentik, Kresen, Bantul. Buletin Peternakan 33:119128.

Widiyanto, M. Soejono, Z. Bachrudin, H. Hartadi, \& Surahmanto. 2007. Pengaruh suplementasi minyak biji kapok terproteksi terhadap daya guna pakan serat secara in vitro. J. Pengembangan Peternakan Tropis 32: 51-57.

Widiyanto, M. Soejono, H. Hartadi, Z. Bachrudin, \& Surahmanto. 2012. Inclusion of kapok seed oil in the diet for growing of thin-tailed sheep to reduce cholesterol and to improve omega-six fatty acid contents of lamb. J. Indonesia Trop. Anim. Agric. 37: 202-212.

Yeates, N. T. M., T. N. Edey, \& M. K. Hill. 1975. Animal Science: Reproduction, Climate, Meat, Wool. 1st published. Pergamon Press, N.S.W. Australia.

Yuniwati, M. 2012. Produksi minyak biji kapuk dalam usaha pemanfaatan biji kapuk sebagai sumber minyak nabati. J. Tek. Technoscientia 4: 202-212.

Yusuf, A. L., Y. M. Goh, A. A. Samsudin, A. R. Alimon, \& A. Q. Sazili. 2014. Growth performance, carcass characteristics and meat yield of boer goats fed diets containing leaves or whole parts of Andrographis paniculata. Asian Australas. J. Anim. Sci. 27: 503-510. http://dx.doi.org/10.5713/ 